\title{
Notes
}

\section{Bisamides from the Twigs of Aglaia perviridis Collected in Vietnam}

\author{
Young-Won Chin, ${ }^{\dagger, \uparrow}$ Hee-Sung Chae, ${ }^{\dagger}$ Joongku Lee, ${ }^{\S}$ Tran The Bach, ${ }^{\#}$ Kyung-Seop Ahn, ${ }^{\dagger}$ Hyeong-Kyu Lee, ${ }^{\dagger}$ \\ Hyouk Joung, ${ }^{\S}$ and Sei-Ryang $\mathrm{Oh}^{\dagger, *}$
}

\author{
${ }^{\dagger}$ Bio-Therapeutics Research Institute, Korea Research Institute of Bioscience and Biotechnology, ChungBuk 363-883, Korea \\ *E-mail: seiryang@kribb.re.kr \\ ${ }^{\ddagger}$ College of Pharmacy, Dongguk University, Seoul 100-715, Korea \\ $\S$ International Biological Material Research Center, Korea Research Institute of Bioscience and Biotechnology, \\ Daejeon 305-806, Korea \\ ${ }^{*}$ Department of Botany, Institute of Ecology and Biological Resources, 18 Hoang Quoc Viet Road, \\ Cau Giay District, Hanoi, Vietnam \\ Received June 6, 2010, Accepted July 5, 2010
}

Key Words: Bisamide, Aglaia perviridis, Nitric oxide, Meliaceae

The genus Aglaia Lour. belongs to the Family Meliaceae and about 120 species is distributed in tropical and subtropical Asia, tropical Australia and Pacific islands. ${ }^{1}$ There are about 30 Aglaia species in Vietnam. Aglaia perviridis is a tree about $15 \mathrm{~m}$ tall and has glabrous lanceolate leaves and ovoid fruit. ${ }^{1,2}$ It is also distributed in Bangladesh, Bhutan, India, Laos, Malaysia, Thailand and Indian ocean islands. ${ }^{1}$ Previous studies for this plant have reported the occurrence of dammarane-type triterpenoids and pregnane steroids. ${ }^{3,4}$ There has been no report regarding pharmacological evaluation for this plant.

As a part of our ongoing search for bioactive compounds with anti-inflammatory activity from plants, a chloroform-soluble extract of $A$. perviridis twigs, collected in Vietnam, was chosen for phytochemical studies due to its inhibitory effect of NO production in the initial screening test. Bioactivity-guided fractionation of a chloroform-soluble fraction of $A$. perviridis twigs led to the isolation of two new compounds (1 and 2) along with a known compound (3) (Fig. 1). Thus, the present study describes the isolation and structure elucidation of all isolates as well as evaluation of inhibitory activity against NO production in LPS-induced RAW 264.7 cells.

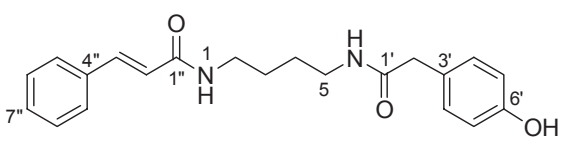

1

Figure 1. Structures of compounds 1-3.

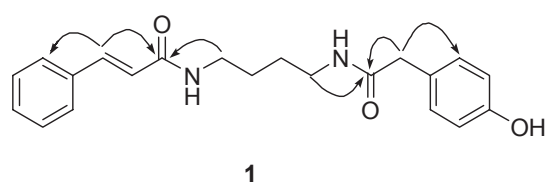

Figure 2. Key HMBC $(\mathrm{H} \rightarrow \mathrm{C})$ correlations of compounds $\mathbf{1}$ and $\mathbf{2}$.
Compound 1 exhibited a pseudomolecular ion peak at $\mathrm{m} / \mathrm{z}$ $353.1840[\mathrm{M}+\mathrm{H}]^{+}$, corresponding to the molecular formula of $\mathrm{C}_{21} \mathrm{H}_{24} \mathrm{~N}_{2} \mathrm{O}_{3}$, in the HRESI-TOF spectrum. The ${ }^{1} \mathrm{H}-\mathrm{NMR}$ spectroscopic data of 1 revealed the presence of a 1,4-butanediamine at $\delta_{\mathrm{H}} 3.30(2 \mathrm{H}, \mathrm{t}, J=6.3 \mathrm{~Hz}, \mathrm{H}-2), 3.20(2 \mathrm{H}, \mathrm{t}, J=6.3$ $\mathrm{Hz}, \mathrm{H}-5)$ and 1.55 (4H, m, H-3 and $\mathrm{H}-4)$, a cinnamoyl moiety at $\delta_{\mathrm{H}} 7.55\left(2 \mathrm{H}, \mathrm{d}, J=7.3 \mathrm{~Hz}, \mathrm{H}-5^{\prime \prime}\right.$ and 9"), 7.38 (2H, m, H-6" and $\left.8^{\prime \prime}\right), 7.36$ (1H, m, H-7"), $7.54\left(1 \mathrm{H}, \mathrm{d}, J=15.8 \mathrm{~Hz}, \mathrm{H}-3^{\prime \prime}\right)$, and $6.60(1 \mathrm{H}, \mathrm{d}, J=15.6 \mathrm{~Hz}, \mathrm{H}-2 ")$, and a 2-(4-hydroxyphenyl) acetic acid moiety at $\delta_{\mathrm{H}} 7.09\left(2 \mathrm{H}, \mathrm{d}, J=8.4 \mathrm{~Hz}, \mathrm{H}-4^{\prime}\right.$ and $\left.8^{\prime}\right)$, $6.72\left(2 \mathrm{H}, \mathrm{d}, J=8.4 \mathrm{~Hz}, \mathrm{H}-5^{\prime}\right.$ and $\left.7^{\prime}\right)$, and 3.38 (2H, s, H-2'). In ${ }^{13} \mathrm{C}-\mathrm{NMR}$ data, two carbon signals for amide were observed at $\delta_{\mathrm{C}} 168.8$ and 174.9 , respectively. Thus, the interpretation of ${ }^{1} \mathrm{H}$-and ${ }^{13} \mathrm{C}$-NMR spectroscopic data indicated that this compound is an analog of cinnamic acid-derived bisamide, reported in the Aglaia species. ${ }^{5}$ The location and position of three units, 1,4-butanediamine, cinnamoyl, and 2-(4-hydroxyphenyl)acetic acid moiety, were completely assigned by the observed HMBC correlations (Fig. 2). Both proton signals at $\delta_{\mathrm{H}} 3.30(\mathrm{H}-2)$ and 6.60 (H-2") showed long-range correlations with the carbonyl signal at $\delta_{\mathrm{C}} 168.8(\mathrm{C}-1 ")$, suggesting the linkage of the cinnamoyl

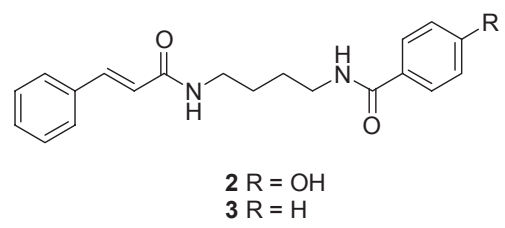

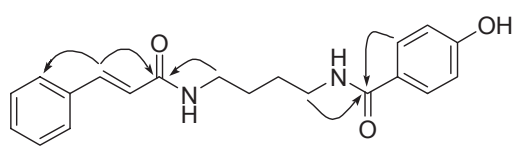

2 
and 1,4-butanediamine. Two- and three-bond correlations of $\delta_{\mathrm{H}} 3.38\left(\mathrm{H}-2^{\prime}\right)$ to $\delta_{\mathrm{C}} 174.9\left(\mathrm{C}-1^{\prime}\right)$ and $131.2(\mathrm{C}-4$ ' and C-8'), respectively, as well as three-bond correlation of $\delta_{\mathrm{H}} 3.20(\mathrm{H}-5)$ to $\delta_{\mathrm{C}}$ 174.9 (C-1') were observed in the HMBC spectrum, accounting for the connection of 1,4-butanediamine and 2-(4-hydroxyphenyl)acetic acid moiety. On the basis of all above data, the structure of compound 1 was determined as $N$-(4-(2-(4-hydroxyphenyl)acetamido)butyl)cinnamamide, as shown in Fig. 1, and named perviridamide.

The ${ }^{1} \mathrm{H}$ spectroscopic data of $\mathbf{2}$ displayed a cinnamoyl moiety at $\delta_{\mathrm{H}} 7.54\left(2 \mathrm{H}, \mathrm{d}, J=7.3 \mathrm{~Hz}, \mathrm{H}-5^{\prime \prime}\right.$ and 9"), 7.38 (2H, m, H-6" and $\left.8^{\prime \prime}\right), 7.35$ (1H, m, H-7"), 7.51 (1H, d, $\left.J=15.7 \mathrm{~Hz}, \mathrm{H}-3 "\right), 6.60$ $\left(1 \mathrm{H}, \mathrm{d}, J=15.7 \mathrm{~Hz}, \mathrm{H}-2^{\prime \prime}\right), 1,4$-butanediamine at $\delta_{\mathrm{H}} 3.35(2 \mathrm{H}$, $\mathrm{t}, J=6.3 \mathrm{~Hz}, \mathrm{H}-2), 3.40(2 \mathrm{H}, \mathrm{t}, J=6.6 \mathrm{~Hz}, \mathrm{H}-5), 1.66(4 \mathrm{H}, \mathrm{m}$, $\mathrm{H}-3$ and $\mathrm{H}-4)$ and a 4-hydroxybenzoic acid moiety at $\delta_{\mathrm{H}} 7.70$ $\left(2 \mathrm{H}, \mathrm{d}, J=8.6 \mathrm{~Hz}, \mathrm{H}-3^{\prime}\right.$ and $\left.7^{\prime}\right), 6.81\left(2 \mathrm{H}, \mathrm{d}, J=8.6 \mathrm{~Hz}, \mathrm{H}-4^{\prime}\right.$ and 6 '), indicating the presence of a cinnamic acid-derived bisamide similar to compound $\mathbf{1}$ except for a 4-hydroxybenzoic acid moiety instead of a 2-(4-hydroxyphenyl)acetic acid moiety in compound $\mathbf{1}$. All assignments of this compound were completed by the observed long-range correlations as depicted in Fig. 2. Therefore, the structure of $\mathbf{2}$ was confirmed as 4-hydroxypyramidatine. The compound $\mathbf{3}$ was identified as pyramidatine by comparison of its data to the published values. ${ }^{5}$

All isolates obtained from active fractions were evaluated for their inhibitory activity against NO production in LPS-induced RAW 264.7 cells, and compounds 1 and $\mathbf{2}$ displayed moderate inhibition of $\mathrm{NO}$ production with $\mathrm{IC}_{50}$ values of 65.3 and 83.4 $\mu \mathrm{g} / \mathrm{mL}$, respectively, while compound $\mathbf{3}$ was found to be inactive.

\section{Experimental Section}

General experimental procedures. UV spectra were obtained with a Shimadzu UV-1601 spectrophotometer. NMR spectroscopic data were recorded at room temperature on a Bruker 900 FT-NMR spectrometer with tetramethylsilane (TMS) as internal standard. Electrospray ionisation (ESI) mass spectrometric analysis was performed with a Waters Q-Tof Premier mass spectrometer (Waters, Manchester, UK). MPLC was performed with a Ceramic Pump VSP-3050 instrument (Eyala, Japan) equipped with a column, $48 \times 3 \mathrm{~cm} 40 \mathrm{C}-18$ resin (Cosmosil, Japan). A YMC J'sphere ODS-H80 column $(250 \times 4.6$ mm I.D., $4 \mu \mathrm{m}$ ) was used for HPLC separation on a Finnigan ChromQuest model instrument (Thermo Electron). Column chromatography was performed using RP-18 resin (Cosmosil $75 \mathrm{C}_{18}$-PREP, Kyoto, Japan). Thin-layer chromatography was carried out on pre-coated Silica gel $60 \mathrm{~F}_{254}(0.25 \mathrm{~mm}$, Merck, Darmstadt, Germany) and RP-18 plates ( 0.25 mm, Merck, Darmstadt, Germany).

Plant material. Twigs of A. perviridis were collected in Vietnam, in January 2008. The plant samples were identified by Tran The Bach, Department of Botany, Institute of Ecology and Biological Resources, Vietnam. A voucher specimen (FBM035051) has been deposited at the herbarium of Korea Research Institute of Bioscience and Biotechnology.

Extraction and isolation. Air-dried twigs of $A$. perviridis (782 g) were extracted by maceration with $\mathrm{MeOH}$ three times
(1000 mL each) at room temperature, for up to 1 day each, with the extractives pooled and then evaporated in vacuo. The dried $\mathrm{MeOH}$ extract $(63 \mathrm{~g})$ was suspended with $\mathrm{H}_{2} \mathrm{O}(500 \mathrm{~mL})$ and partitioned sequentially with hexane $(3 \times 500 \mathrm{~mL})$ and $\mathrm{CHCl}_{3}$ $(3 \times 500 \mathrm{~mL})$. Of these, the $\mathrm{CHCl}_{3}$-soluble partition $(3.5 \mathrm{~g})$ exhibited the inhibition of $\mathrm{NO}$ production $(79 \%$ inhibition at $20 \mu \mathrm{g} / \mathrm{mL}$ ), using the protocol indicated below. The $\mathrm{CHCl}_{3}$ soluble fraction $(3.5 \mathrm{~g})$ was subjected to a silica gel column chromatography with a stepwise gradient mixture of $\mathrm{CHCl}_{3}$ $\mathrm{MeOH}(100: 0 \rightarrow 50: 50, \mathrm{v} / \mathrm{v})$ to yield 11 fractions (F01-F11). Of these fractions, F04 and 07 were found to inhibit NO production (53 and 64\%), respectively, at a concentration of 20 $\mu \mathrm{g} / \mathrm{mL})$. Pyramidatine $(3,40 \mathrm{mg}$ ) was purified from the precipitate in sub-fraction F04. A portion of fraction F07 $(247 \mathrm{mg}$ ) was separated by HPLC using a YMC J'sphere ODS column $\left(\mathrm{MeOH}-\mathrm{H}_{2} \mathrm{O}=47: 53,7 \mathrm{~mL} / \mathrm{min}\right)$ to give compounds 1 (16 mg, $\left.t_{\mathrm{R}} 47 \mathrm{~min}\right)$ and $2\left(14 \mathrm{mg}, t_{\mathrm{R}} 53 \mathrm{~min}\right)$.

Compound (1): Amorphous powder; UV (MeOH) $\lambda_{\max }$ $(\log \varepsilon) 274$ (4.25) nm; IR (film) $v_{\max } 3282,2950,1633,1542$, $1514,1447 \mathrm{~cm}^{-1}$; HRESIMS (positive ion mode) $\mathrm{m} / \mathrm{z} 353.1840$ $[\mathrm{M}+\mathrm{H}]^{+}$(Calcd for $\left.\mathrm{C}_{21} \mathrm{H}_{25} \mathrm{~N}_{2} \mathrm{O}_{3} 353.1865\right) ;{ }^{1} \mathrm{H}-\mathrm{NMR}\left(\mathrm{CD}_{3} \mathrm{OD}\right.$, $900 \mathrm{MHz}): 7.55\left(2 \mathrm{H}, \mathrm{brd}, J=7.3 \mathrm{~Hz}, \mathrm{H}-5^{\prime \prime}\right.$ and $\left.9 "\right), 7.54(1 \mathrm{H}$, $\mathrm{d}, J=15.8 \mathrm{~Hz}, \mathrm{H}-3 "), 7.38$ (2H, m, H-6" and 8"), 7.36 (1H, m, H-7"), 7.09 (2H, d, $J=8.4 \mathrm{~Hz}, \mathrm{H}-4$ ' and $\left.8^{\prime}\right), 6.72(2 \mathrm{H}, \mathrm{d}, J=8.4$ $\mathrm{Hz}, \mathrm{H}-5^{\prime}$ and 7'), 6.60 (1H, d, $\left.J=15.6 \mathrm{~Hz}, \mathrm{H}-2^{\prime \prime}\right), 3.38(2 \mathrm{H}, \mathrm{s}$, H-2'), 3.30 (2H, t, $J=6.3 \mathrm{~Hz}, \mathrm{H}-2), 3.20(2 \mathrm{H}, \mathrm{t}, J=6.3 \mathrm{~Hz}$, $\mathrm{H}-5), 1.55$ (4H, m, H-3 and H-4); ${ }^{13} \mathrm{C}-\mathrm{NMR}\left(\mathrm{CD}_{3} \mathrm{OD}, 225 \mathrm{MHz}\right)$ 174.9 (C-1'), 168.8 (C-1"), 157.6 (C-6'), 141.8 (C-3"), 136.5 (C-4"), 131.2 (C-4' and 8'), 130.9 (C-7"), 130.1 (C-6" and C-8"), 129.0 (C-5" and 9"), 127.8 (C-3'), 122.0 (C-2"), 116.5 (C-5' and C-7'), 43.3 (C-2'), 40.3 (C-2 and C-5), 28.0 (C-3*), C-27.9 $(\mathrm{C}-4 *)$.*The assignments are interchangeable.

Compound (2): Amorphous powder; UV (MeOH) $\lambda_{\max }$ $(\log \varepsilon) 266(3.82) \mathrm{nm}$; IR (film) $v_{\max } 3286,2925,1650,1610$, $1537,1503,1448 \mathrm{~cm}^{-1}$; HRESIMS (positive ion mode) $\mathrm{m} / \mathrm{z}$ 339.1682 [M+H] $]^{+}$(Calcd for $\left.\mathrm{C}_{20} \mathrm{H}_{23} \mathrm{~N}_{2} \mathrm{O}_{3} 339.1709\right) ;{ }^{1} \mathrm{H}-\mathrm{NMR}$ $\left(\mathrm{CD}_{3} \mathrm{OD}, 900 \mathrm{MHz}\right): 7.70\left(2 \mathrm{H}, \mathrm{d}, J=8.6 \mathrm{~Hz}, \mathrm{H}-3^{\prime}\right.$ and $\left.7{ }^{\prime}\right), 7.54$ $\left(2 \mathrm{H}, \mathrm{brd}, J=7.3 \mathrm{~Hz}, \mathrm{H}-5^{\prime \prime}\right.$ and 9"), $7.51(1 \mathrm{H}, \mathrm{d}, J=15.7 \mathrm{~Hz}$, H-3"), 7.38 (2H, m, H-6" and 8"), 7.35 (1H, m, H-7"), $6.81(2 \mathrm{H}$, $\mathrm{d}, J=8.6 \mathrm{~Hz}, \mathrm{H}-4^{\prime}$ and $\left.6^{\prime}\right), 6.60\left(1 \mathrm{H}, \mathrm{d}, J=15.7 \mathrm{~Hz}, \mathrm{H}-2^{\prime \prime}\right)$, $3.40(2 \mathrm{H}, \mathrm{t}, J=6.6 \mathrm{~Hz}, \mathrm{H}-5), 3.35$ (2H, overlapped, H-2), 1.66 (4H, m, H-3 and $\mathrm{H}-4) ;{ }^{13} \mathrm{C}-\mathrm{NMR}\left(\mathrm{CD}_{3} \mathrm{OD}, 225 \mathrm{MHz}\right) 170.3$ (C-1'), 168.8 (C-1"), 162.3 (C-5'), 141.8 (C-3"), 136.5 (C-4"), 130.9 (C-7"), 130.3 (C-3' and 7'), 130.1 (C-6" and C-8"), 128.9 (C-5" and 9"), 127.8 (C-3'), 126.6 (C-2'), 122.1 (C-2"), 116.3 (C-4' and C-6'), 40.7 (C-5), 40.4 (C-2), 28.2 (C-3*), C-28.1 (C-4*).*The assignments are interchangeable.

MTT assay for cell viability. The cell viability was examined by MTT assay. ${ }^{6}$ In brief, RAW 264.7 cells were seeded at a density of $5 \times 10^{4} / \mathrm{mL}$ in 96 well plates (Nunc, Denmark). Each batch of cells included a non-treated group as control. Test samples were then added to each well, after which the plates were incubated for $24 \mathrm{~h}$ at $37^{\circ} \mathrm{C}$ under $5 \% \mathrm{CO}_{2}$. Next, MTT solutions $(5 \mathrm{mg} / \mathrm{mL})$ were added to each well, and the samples were then cultured for an additional $4 \mathrm{~h}$. The supernatant was then discarded and $100 \mu \mathrm{L}$ of dimethyl sulfoxide (DMSO) was added to each well. Next, the optical density was read at $590 \mathrm{~nm}$. The cytotoxicity was then calculated by subtracting the ratio 
of the mean absorbance value for treated cells over the mean absorbance value for untreated cells from one.

Measurement of NO production. NO production was assayed by measuring the nitrite in the supernatants of cultured RAW 264.7 cells. $^{6}$ Briefly, the cells were seeded at a density of $5 \times$ $10^{5} / \mathrm{mL}$ in 96 well culture plates. After pre-incubation incubation for $18 \mathrm{~h}$, the cells were pretreated for $30 \mathrm{~min}$ with test samples and then stimulated with LPS $(200 \mathrm{ng} / \mathrm{mL})$ for $24 \mathrm{~h}$. The supernatant was then mixed with an equal volume of Griess reagent ( $1 \%$ sulfanilamide, $0.1 \%$ naphthylethylenediamine dihydrochloride, and $2.5 \%$ phosphoric acid) and then incubated at room temperature for $5 \mathrm{~min}$. The concentration of nitrite was then determined by measuring the absorbance at $570 \mathrm{~nm}$ and comparing the values to a standard curve generated using sodium nitrite $\left(\mathrm{NaNO}_{2}\right)$.

Acknowledgments. This research was supported by a grant (FGS1010924) from the Construction of Foreign Plant Extract
Library, funded by the Ministry of Science and Technology of the Korean government. We are grateful to Eun-Hee Kim, Korea Basic Science Institute, for the NMR spectral data.

\section{References and Notes}

1. Wu, Z.; Raven, P. H.; Hong, D. Flora of China; Missouri Botanical Garden Press: Vol. 11, p 121, 2008.

2. Lee, H. A. An Illustrated Flora of Vietnam; Chi Nhanh Taia Hanoi: Vol. II., pp 385-405, 2002.

3. Yang, S.-M.; Tan, C.-H.; Luo, H.-F.; Wang, D.-X.; Zhu, D.-Y. Hel. Chim. Acta 2008, 91, 333.

4. Yang, S.-M.; Fu, W.-W.; Wang, D.-X.; Tan, C.-H.; Zhu, D.-Y. J. Asian Nat. Prod. Res. 2008, 10, 459.

5. Saifh, E.; Puripattanavong, J.; Likhitwitayawuid, K.; Cordell, G. A.; Chai, H.; Pezzuto, J. M. J. Nat. Prod. 1993, 56, 473.

6. Chae, H.-S.; Kang, O.-H.; Choi, J.-G.; Oh, Y.-C.; Lee, Y.-S.; Jang, H.-J.; Kim, J. H.; Park, H.; Jung, K. Y.; Sohn, D. H.; Kwon, D.-Y. Biol. Pharm. Bull. 2009, 32, 553. 